Antenatal Diagnosis of Spina Bifida R. Harris, M.D., and others; G. M. Addison, M.B, and others Alternatives to the Fluoridation of Water D. Jackson, D.D.S....................... Induction of Labour and Perinatal Mortality Mortality A. Singer, M.R.C.o.G., and I. D. Cooke,
F.R.C.o.G. F.R.C.O.G.
Dangers of Silent Gail Stones

D. A. Jennings, B.M............... 35

Reactions to Practolol

W. A. Stubbs, M.R.C.S., and M. B. Ablett, M.B. 36 Neonatal Hyperthyroidism and Longacting Thyroid Stimulator Protector

J. A. Thomson, F.R.C.P.GLAS., and others. . . 36

Treatment of Herpes Simplex with Cotrimoxazole

Paula J. H. Gosling, M.B.

Paula J. H. Gosling, M.B................ 36

ranquilizers Causing Aggression

CH..............36

Postoperative Management after

Thymectomy

L. Loh, F.F.A.R.C.S., and J. M. Newsom Davis,

F.R.C.P.; M. J. Lange, F.R.C.S. and T. H.
Howells, F.F.A.R.c.S. . . .
Measurement of Neonatal Growth

D. P. Davies, M.R.C.P................... 37

Misleading Drug Advertising

A. J. Jouhar, M.B................. 38

Treatment of Sciatica

G. Symonds, M.B...

Overseas Doctors in the U.K.

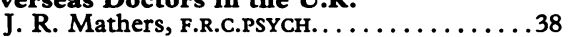

Distribution of Hospital Provision

M. J. McCarthy, M.F.C.M.; D. P. Forster,

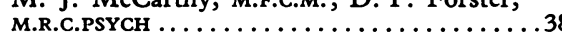

Surgery in Rhodesia

S. V. Humphries, F.R.C.s. . . . . . . . . . 39

Specialists in Community Medicine

D. G. H. Patey, M.F.C.M.............. 39

Geriatric Chairs

K. Jones, F.R.C.P.I. . . . . . . . . . . . . 39

The Samaritans

Doris M. Odlum, F.R.C.PSYCH........... 39

Treatment of Protein-losing

Gastroenteropathy

M. Kondo, M.D., and others. . . . . . . . .40

Illness in the Clouds

R. J. Fairhurst, M.в.............40
Heberden's Angina and Syncope Anginosa

B. Livesley, M.R.C.P. . . . . . . . . . . . 40

Kilo-what?

D. B. Jelliffe, F.R.C.P., and E. F. Patrice Jelliffe, M.P.н. ................40 Consultant Contract

C. P. Lowther, F.R.C.P.ED.; R. S. Francis, F.R.C.P., and others; H. Miller, F.R.c.PATH.. .40

Salaries of Research Workers

R. Schofield, PH.D., and others........41

Fees for Insurance Reports

J. P. Lask, M.R.C.G.P...........41

Polarization of Attitudes

A. W. M. Gammon, M.B............41

Points from Letters Laparoscopic Sterilization (A. D. Noble); Sea Urchin Spine Injury: Unorthodox Treatment (Lieutenant-Colonel C. M. J. O'Rorke); Special Diets in Hospital (E. A Wilson); The Sleeping Baby (Louise F. W. Eickhoff); Routine Chest Radiographs in Hospital (P. O. Leggat); Gestation Age for Abortion C. B. Goodhart); Financing General Practice (G. D. H. Shephard); Kilopascals (C. L Tolhurst-Cleaver) $\ldots \ldots \ldots \ldots \ldots \ldots \ldots .42$
Correspondents are urged to write briefly so that readers may be offered as wide a selection of letters as possible. So many are now being received that the omission of some is inevitable. Letters should be signed personally by all their authors.

\section{Antenatal Diagnosis of Spina Bifida}

SIR,-Further to your leading article (22 February, p. 414) we can add further reports of cases of spina bifida detected by amniotic $\alpha$-fetoprotein (AFP) assay and, though serious closed lesions may be missed, the test is a good one. ${ }^{1}$ We also agree that maternal serum AFP assay is currently able to detect at 16-20 weeks about one-third of cases of spina bifida. ${ }^{1}$ You conclude that, in spite of being associated with at least $2 \%$ false positives, pregnant women with a risk of 1 in 20 of bearing a fetus with spina bifida can be identified, and general screening of all pregnancies by maternal serum AFP assay should now be considered. This is surprising since the assay teohnique is still subject to much inter-laboratory variation. it misses two-thirds of cases of spina bifida and there are many practical and ethical problems still to be solved.

A minor revolution in obstetric practice would be necessary to obtain at 14-16 weeks serum from 800000 pregnant women annually, especially in those areas where the majority do not book until later. Is it ethically justifiable to perform maternal serum assays on women who would never accept a termination of pregnancy, and should every woman undergoing this test be warned that amniocentesis would be indicated if the serum test is positive? Though unnecessary for the majority of anencephalics (detectable by ultrasound alone) 14000 amniocenteses per year might be required, and it is doubtful whether sufficient equipment and trained technicians are available to allow preliminary ultrasound scan, without which the risks of amniocentesis may rise. Unwanted abontion currently results from amniocentesis in approximately $1-2 \%$ of cases $^{2}$ and consequently each year 140-280 normal, wanted fetuses might be jeopardized. It is also generally agreed that chromosome studies should be carried out on specimens of amniotic fluid taken for AFP assay, but this is not always possible with the resources at present provided. It would be quite impossible on 14000 amniotic fluid specimens a year and mongols would be missed.

Though the value to individual women of antenatal diagnosis is undisputed, ${ }^{3}$ population screening with a view to selective abortion is rather different and we must avoid the precipitate introduction of an unvalidated and costly screening programme based upon studies involving selected high-risk pregnancies which may not be representative of the general population of pregnant women. It is hoped that the enthusiasm created by your leading article will be ohannelled into well-controlled pilot studies of maternal serum assay and the establishment of regional teams providing specialized obstetric, radiological, genetic, and biochemical services directed to the improved antenatal detection of all birth defects.-We are, etc.,

\section{R. HARRIS}

R. F. JENNISON

A. J. Barson

Department of Medical Genetics and Pathology,

St. Mary's Hospital, Manchester

1 Harris, R., et al., Lancet, 1974, $1,429$.

2 British Medical Fournal, 1974, 4, 676 . Abortion. London, Nuffield Provincial Hospitals Trust, 1974 .
SIR,-Estimation of maternal serum $\alpha$ fetoprotein (AFP) may prove to be of value in the clinical management of high-risk pregnancies, but the use of this test for antenatal mass screening for neural tube defects would represent such a fundamental change in obstetric practice that the implications of such a policy must be carefully evaluated before this procedure is introduced. We endorse the need for a scientific approach to the practical and ethical problems involved, but consider the rallying call in the last sentence of your leading article (22 February, p. 414) to be premature.

The need for careful investigation of the problems involved in measuring maternal serum AFP in order to define at the very least reliable estimates of test reproducibility, sensitivity, and specificity and the optimum time for the serum test is self-evident. In addition, public attitudes to the procedure need to be examined-for example, should patients be informed that blood is being taken for screening; should the benefits of compliance be stated; are there any hazards of compliance and if so what are they and should patients be informed?

Our concern that this screening procedure should be properly validated is further increased by the knowledge that a commercial kit for AFP radioimmunoassay is now available and doubtless others will soon be appearing on the market. Though these kits have a role to play in other branches of medicine, knowledge of their availability is certain to make it more difficult for obstetricians and chemical pathologists to resist the establishment of local screening programmes before their value has been properly established.

Hasty application of such tests will bring in its wake a great deal of unnecessary anguish (and possible risks to an otherwise normal pregnancy) for patients with false- 